\title{
In vitro availability of zinc from infant foods with increasing phytic acid contents
}

\author{
Douwina Bosscher ${ }^{1 *}$, Zhengli Lu ${ }^{1}$, Geert Janssens ${ }^{2}$, Micheline Van Caillie-Bertrand ${ }^{3}$, \\ Harry Robberecht ${ }^{1}$, Herman De Rycke ${ }^{2}$, Roland De Wilde ${ }^{2}$ and Hendrik Deelstra ${ }^{1}$ \\ ${ }^{1}$ Department of Pharmaceutical Sciences, Laboratory of Food Sciences, University of Antwerp (UIA), Universiteitsplein 1, \\ 2610 Antwerp (Wilrijk), Belgium \\ ${ }^{2}$ Department of Animal Nutrition, Animal Genetics, Breeding and Ethology, Ghent University, Heidestraat 19, 9820 \\ Merelbeke, Belgium \\ ${ }^{3}$ Department of Paediatric Gastroenterology and Nutrition, Koningin Paola Kinderziekenhuis, Algemeen Ziekenhuis \\ Middelheim (AZM), Lindendreef 1, 2020 Antwerp, Belgium
}

(Received 1 August 2000 - Revised 20 February 2001 - Accepted 9 March 2001)

\begin{abstract}
An in vitro method was used to determine the availability of $\mathrm{Zn}$ from infant foods containing increasing amounts of phytate, and to quantify the effect of the phytate:Zn molar ratio on the availability. During the in vitro assay, digestive conditions of infants, younger and older than 4 months of age, were carefully simulated since the solubility of phytate- $\mathrm{Zn}$ complexes during digestion is $\mathrm{pH}$ dependent. Availability was measured with a continuous flow dialysis in vitro procedure with previous intralumen digestive stage. $\mathrm{Zn}$ concentrations were determined with flame atomic absorption spectrometry. Phytic acid content was measured with HPLC. Adding phytate to infant formula lowered Zn availability to $2 \cdot 84$ (SD $0 \cdot 17$ ) $\%$ when the phytate:Zn molar ratio increased to $2.2(P<0.05)$, as compared with cows' milk-based formula (6.65 (SD 0.55) $\%)$. Availability from vegetables $(23.83($ SD 2.17$) \%)$ significantly decreased $(P<0.05)$ at a ratio $>7.9(15 \cdot 12(\mathrm{SD} 1.63) \%)$. Zn availability from soyabean-based formula $(2 \cdot 26(\mathrm{SD} 0.36) \%)$ was lower $(P<0.05)$ compared with cows' milk-based formula (6.65 (SD 0.55) \%). Availability between soyabean- and cows' milk-based formula was similar $(P>0.05)$ when a phytate:Zn ratio of $2 \cdot 2(2 \cdot 84(\mathrm{SD} 0 \cdot 17) \%)$ was obtained in the cows' milk formula. The negative effect of phytic acid on $\mathrm{Zn}$ availability was dependent on the type of the food and the phytate content, and should be considered when using soyabean-based formulas during early infancy.
\end{abstract}

Bioavailability of micronutrients: Zinc: Phytate: Infants: In vitro method

Phytic acid naturally occurs in many foods derived from plants. It is the storage form of $\mathrm{P}$ in most seeds. Of the total amount of $\mathrm{P}$ in plants, approximately $60-90 \%$ is found as phytate (Cheryan, 1980). Phytic acid forms strong ionic complexes (phytates) with many essential bi- and trivalent metal ions in foods as well as in the intestine (Nolan \& Duffin, 1987; Frølich, 1990). The presence of phytate has therefore been shown to have an inhibitory effect on the bioavailability of minerals and trace elements (Reddy et al. 1982; Bosscher et al. 1998b). The influence of phytate on Ca (Heaney et al. 1991; De Vizia \& Mansi, 1992), Fe (Sandberg et al. 1989, 1993), and Zn (Wise, 1995; Rimbach et al. 1998) bioavailability has been extensively studied in vitro as well as in vivo. $\mathrm{Zn}$ is reported to be the essential element most adversely affected by phytate (Torre \&
Rodriguez, 1991; Van Dyck et al. 1996). The binding of Zn by phytate is dependent on several factors such as the amount of phytate, $\mathrm{pH}$, and the presence of other metal ions. At raised stomach $\mathrm{pH}$ values, as can be found in infants (Vandenplas, 1992), Zn complexes with phytate yet enter the duodenum in an insoluble form (Champagne, 1988). In addition, infant formulas are often supplemented with relatively large amounts of $\mathrm{Ca}$ and $\mathrm{Fe}$, which may further interact with $\mathrm{Zn}$ absorption, leading to reduced bioavailability (Morris \& Ellis, 1980; Bougle et al. 1999). Zn deficiency may lead to deficits in children's growth and development and immunological function, which can result in delayed cognitive performance (Black, 1998) and may increase their susceptibility to a variety of pathogens (Shankar \& Prasad, 1998). 
A previous study performed in our laboratory has demonstrated that the availability of $\mathrm{Zn}$ in soyabean-based infant formula is significantly lower than in whey- or caseinbased formula in vitro. It was speculated that the low availability of $\mathrm{Zn}$ from the soyabean-based formula was due to its phytate content (Bosscher et al. 2001). The present study was designed to determine from which baseline phytate level onwards, phytate might inhibit $\mathrm{Zn}$ availability. Two different food matrices were used: infant formula and a homogenised vegetable (green beans; Phaseolus vulgaris) preparation, to which increasing amounts of phytate were added. The term 'availability' is used throughout this work to describe the bioavailability of $\mathrm{Zn}$ from the foods in vitro. Bioavailability can be used as a large concept including digestion, absorption, and incorporation into metabolic processes. It can also be used in a narrow sense, meaning that any potentially available part of a nutrient after gastrointestinal digestion should be attributed as bioavailability (Bender, 1989; Jackson, 1997).

\section{Materials and methods}

\section{Samples, reagents, and materials}

The infant formulas were soyabean- and cows' milk-based that are frequently used during the first months of infancy. Infant formulas are currently supplemented with minerals and essential trace elements during the manufacturing process (Table 1). From the age of 4 months on, babies are generally fed homogenised solid foods. A green bean preparation was chosen as a control food because of its low phytic acid content (Table 1). The energy and nutrient composition of the samples is given in Table 1. The energy, protein, fat, and carbohydrate content were taken from manufacturer's information. The \% DM was calculated after lyophilisation of the food. The $\mathrm{Ca}$ and $\mathrm{Zn}$ contents were measured by atomic absorption spectrometry and the phytic acid content was measured by HPLC (Sandberg \& Adherinne, 1986; H De Rycke, M Seynaeve and R De Wilde, unpublished results). Phytate (as magnesium potassium salt, P 7660) was obtained from Sigma (St Louis, MO, USA). All chemicals (Merck, Darmstadt, Germany) were of analytical grade. Bi-distilled water (MilliQ; Millipore, Bedford, MA, USA) was used throughout the study. Digestive enzymes and bile salts were purchased from Sigma and Merck. Pepsin (P-7000, from porcine stomach mucosa), pancreatin (107133 0500, porcine) and bile salt (B-8631, porcine) concentrations were specified according to the developing stage of the gastrointestinal tract that had to be simulated in vitro (Bosscher et al. 1998a). For the preparation of infant formulas (method 1): a pepsin solution was made by dissolving $1.5 \mathrm{~g}$ pepsin in $15 \mathrm{ml} 0.1 \mathrm{M}-\mathrm{HCl}$. The pancreaticbile mixture contained $0.3 \mathrm{~g}$ pancreatin and $0.7 \mathrm{~g}$ bile in $100 \mathrm{ml} 0 \cdot 1 \mathrm{M}-\mathrm{NaHCO}_{3}$. For the experiments with green beans (method 2): the pepsin solution contained $3 \mathrm{~g}$ pepsin in $15 \mathrm{ml} 0 \cdot 1 \mathrm{M}-\mathrm{HCl}$ and the pancreatic-bile mixture was prepared by adding $5.6 \mathrm{~g}$ pancreatin and $2.1 \mathrm{~g}$ bile to $100 \mathrm{ml}$ $0 \cdot 1 \mathrm{M}-\mathrm{NaHCO}_{3}$.

The dialysis bags (10-12 kDa, Visking 3-20/32; Medicell Ltd, London, UK) were free from trace metal impurities by boiling in $0 \cdot 24 \mathrm{M}-\mathrm{NaHCO}_{3}$ with $0 \cdot 01 \mathrm{M}$-EDTA solution and $0.003 \mathrm{M}$-SDS, followed by thorough washing with bidistilled water.

\section{Equipment}

Dialysis cells (model 8200, $200 \mathrm{ml}$ ) and related dialysis membranes (molecular weight cut off (MWCO) 1000) were purchased from Amicon Ltd (Beverly, CA, USA). Prior to use, the cells were rinsed with $1.44 \mathrm{M}-\mathrm{HNO}_{3}$ and washed with bi-distilled water. Dialysis membranes were soaked in $0 \cdot 1 \mathrm{M}-\mathrm{NaOH}$ and washed with bi-distilled water.

\section{Continuous flow dialysis method with preliminary digestive stage in vitro}

The method consisted of an intralumen digestive stage (Bosscher et al. 2000), adapted to the gastrointestinal conditions of infants younger or older than 4 months of age (Bosscher et al. 1998a), followed by a dialysis procedure in which dialysable food components were continuously removed from the digest (Minihane et al. 1993; Shen et al. 1994). The method consisted of two phases: a gastric and an intestinal stage. Prior to the gastric stage, the $\mathrm{pH}$ of the food sample was lowered to $\mathrm{pH} 2 \cdot 0$ (infants older than 4 months of age, method 1) or 4.0 (younger than 4 months of age, method 2) with $6 \mathrm{M}-\mathrm{HCl}$, and $3 \mathrm{ml}$ freshly prepared pepsin

Table 1. Gross energy and nutrient content of the samples*

\begin{tabular}{|c|c|c|c|c|c|c|c|c|c|c|c|c|}
\hline & \multirow[b]{2}{*}{$\mathrm{DM}(\mathrm{g})$} & \multirow{2}{*}{$\begin{array}{c}\text { Gross } \\
\text { energy } \\
(\mathrm{kJ})\end{array}$} & \multirow{2}{*}{$\begin{array}{l}\text { Protein } \\
\quad(g)\end{array}$} & \multirow{2}{*}{$\begin{array}{l}\text { Fat } \\
\text { (g) }\end{array}$} & \multirow{2}{*}{$\begin{array}{l}\text { Carbohydrate } \\
\text { (g) }\end{array}$} & \multirow{2}{*}{$\begin{array}{l}\text { Phytic } \\
\text { acid } \\
\text { (mg)† }\end{array}$} & \multicolumn{2}{|c|}{$\mathrm{Ca}(\mathrm{mmol})$} & \multicolumn{2}{|c|}{$\mathrm{Fe}(\mu \mathrm{mol})$} & \multicolumn{2}{|c|}{$\mathrm{Zn}(\mu \mathrm{mol})$} \\
\hline & & & & & & & Mean & SD & Mean & SD & Mean & SD \\
\hline \multicolumn{13}{|l|}{ Infant formulał } \\
\hline Cows' milk-based (/l) & 131 & 2800 & 14 & 35 & 75 & - & 13.5 & 0.4 & 97.8 & 3.5 & $85 \cdot 3$ & 1.5 \\
\hline Soyabean-based (/I) & 127 & 2760 & 18 & 36 & 67 & 73.5 & 16.5 & 0.4 & 233 & 3 & 122 & 4 \\
\hline \multicolumn{13}{|l|}{ Vegetables } \\
\hline $\begin{array}{l}\text { Green beans } \\
\quad \text { (Phaseolus vulgaris) (/kg) }\end{array}$ & 103 & 1800 & 22 & 2 & 110 & $11 \cdot 8$ & $10 \cdot 2$ & 0.5 & 234 & 2 & $40 \cdot 6$ & $4 \cdot 1$ \\
\hline
\end{tabular}

${ }^{*}$ Energy, protein and fat contents were taken from the manufacturer's information. DM was calculated after lyophilisation of a sample. Calcium and zinc were measured by atomic absorption spectrometry and phytate by HPLC (for details, see p. 243).

†Phytic acid: inositol hexaphosphate.

$\ddagger$ Calculations were based on normal reconstitution of infant formula powder with water (thirty spoons powder $+850 \mathrm{ml}$ water to give 1 litre formula). 
solution was added. The sample was incubated in a shaking water bath for $2 \mathrm{~h}$ at $37^{\circ} \mathrm{C}(120$ strokes/min). The intestinal stage was performed in a dialysis cell with a dialysis membrane (MWCO, 1000) under a pressure of $350 \mathrm{kDa}$ for continuous flow. The dialysis cell contained a dialysis bag $(10-12 \mathrm{kDa})$, with an amount of $\mathrm{NaHCO}_{3}$ to gradually increase the $\mathrm{pH}$ to 7 as the chyme left the stomach and entered the intestine. After $30 \mathrm{~min}$ of dialysis, the pancreatic-bile mixture was added to the cell and dialysis was continued for another $2 \mathrm{~h}$. The whole procedure was undertaken four times for each sample and/or blank investigated.

\section{Acid destruction of food samples}

Before acid destruction of the food, various aliquots of about $100 \mathrm{~g}$ were freeze-dried (GTL, Leybold, Heraeus, Germany). About $0.4 \mathrm{~g}$ lyophilised material was placed into a Teflon vial of a polypropylene destruction bomb. Bidistilled water $(1 \mathrm{ml}), \mathrm{H}_{2} \mathrm{O}_{2}$ (suprapure, $300 \mathrm{ml} / \mathrm{l}, 500 \mu \mathrm{l}$ ), and $\mathrm{HNO}_{3}$ (suprapure, $650 \mathrm{ml} / \mathrm{l}, 2 \mathrm{ml}$ ) were added and the closed vessel was placed in a microwave digestion oven with a turntable (Hendrix et al.1998). The lyophilisation procedure was performed in duplicate and acid destructions of the food in quadruplicate.

\section{Atomic absorption spectrometry}

The $\mathrm{Zn}$ concentration of the samples and dialysate fractions was determined by flame atomic absorption spectrometry. A Perkin-Elmer Analyst 300 atomic absorption spectrometer (Perkin-Elmer; Norwalk, CT, USA) was used in all measurements.

\section{HPLC}

The content of phytic acid and inositol phosphates was determined by HPLC with a pulsed electrochemical detector (Dionex, Sunnyvale, CA, USA), as described by H De Rycke, M Seynaeve and R De Wilde, unpublished results.

\section{Calculation of the phytate:zinc molar ratio and (phytate $\times$ calcium):zinc ratio}

To calculate the phytate: $\mathrm{Zn}$ molar ratio of the infant food, the amount of phytate $(\mathrm{mg})$ present in $100 \mathrm{~g}$ infant food was divided by the molecular mass of the inositol phosphate, and the result was divided by the total amount of $\mathrm{Zn}(\mathrm{mmol})$ in $100 \mathrm{~g}$ of the same food. To find the (phytate $\times \mathrm{Ca}$ ): $\mathrm{Zn}$ molar ratio, the total amount of $\mathrm{Ca}(\mathrm{mmol})$ in $100 \mathrm{~g}$ infant food was multiplied by the phytate: $\mathrm{Zn}$ ratio. The final result was then recalculated per $1 \mathrm{~kg}$.

\section{Calculation of the zinc availability}

The availability of the element was calculated from the amount of element in the dialysate (corrected for blank), in proportion to the total elemental content of the original infant food sample. The following equation was used:

$$
\mathrm{Zn} \text { availability }(\%)=\frac{(\mathrm{D}-\mathrm{Bl})}{\mathrm{W} \times \mathrm{A}} \times 100,
$$

where $\mathrm{D}$ was the amount of element in the dialysate after digestion $(\mu \mathrm{g}), \mathrm{Bl}$ was the amount of element in the blank dialysate after digestion $(\mu \mathrm{g}), \mathrm{W}$ was the dry weight of the food sample used for intestinal digestion $(\mathrm{g})$, and A was the concentration of element in the food sample $(\mu \mathrm{g} / \mathrm{g})$.

\section{Assessment of the analytical performance of the in vitro procedure}

Initial standardisation was achieved by preparing two aqueous $\mathrm{Zn}$ solutions at concentrations of $0.08 \mathrm{mmol} / \mathrm{l}$ (sample 1) and $0.15 \mathrm{mmol} / \mathrm{l}$ (sample 2), and by using these solutions during digestion and following dialysis to determine recovery of the procedure as described for infants younger (method 1) or older (method 2) than 4 months of age. The repeatability of both procedures was calculated from the $\mathrm{Zn}$ availability of the infant formula and of the vegetable preparation on four occasions over $1 \mathrm{~d}$ (intra-batch precision). Blanks were taken through the entire procedure and $\mathrm{Zn}$ content was measured to correct for element contamination from reagents, equipment or enzymes.

\section{Statistical analysis}

One-way ANOVA procedures were applied by using Sigma Stat (SPSS Inc. Software and Services; San Rafall, CA, USA). Differences were considered statistically significant at $P<0 \cdot 05$. Values are means and standard deviations $(n 4)$.

\section{Results}

Validation criteria for the atomic absorption spectrometric technique

Accuracy of the technique for $\mathrm{Ca}$ and $\mathrm{Zn}$ was checked before the start of every assay by analysing non-fat milk powder (NBS 1549; National Bureau of Standards, Gaithersberg, FL, USA), which yielded values of 46.93 (SD 0.02) $\mu \mathrm{g} \mathrm{Zn/g}$ and 13.3 (SD 0.25) $\mathrm{mg} \mathrm{Ca} / \mathrm{g}$ that fell between the boundaries of the certified value $(46 \cdot 1$ (SD 2.2) $\mu \mathrm{g} \mathrm{Zn/g,} 1.30$ (SD 0.05) $\mathrm{mg} \mathrm{Ca/g}$ ). Precision of the atomic absorption spectrometric technique was tested on a standard solution for $\mathrm{Ca}(2 \mathrm{mg} / \mathrm{l})$ and $\mathrm{Zn}(0.2 \mathrm{mg} / \mathrm{l})$, and yielded values of $0.98 \%$ for $\mathrm{Ca}$ and $1.01 \%$ for $\mathrm{Zn}$.

\section{Validation criteria for the HPLC technique}

To determine accuracy of the technique standard solutions of 10 ( $n$ 4), 25 ( $n$ 5), 50 ( $n$ 10), 60 ( $n$ 4), and $100 \mathrm{mg} / \mathrm{l}(n$ 10) were measured individually on subsequent days and linearity of the regression curve was determined. Linearity was highly significant in the range of $10-100 \mathrm{mg} / \mathrm{l}\left(r^{2}\right.$ 0.996, $P<0.001)$. Precision of the HPLC technique was tested on a $50 \mathrm{mg} / \mathrm{l}$ standard solution $(n 10)$ and yielded a $\mathrm{CV}$ of $4 \%$. 


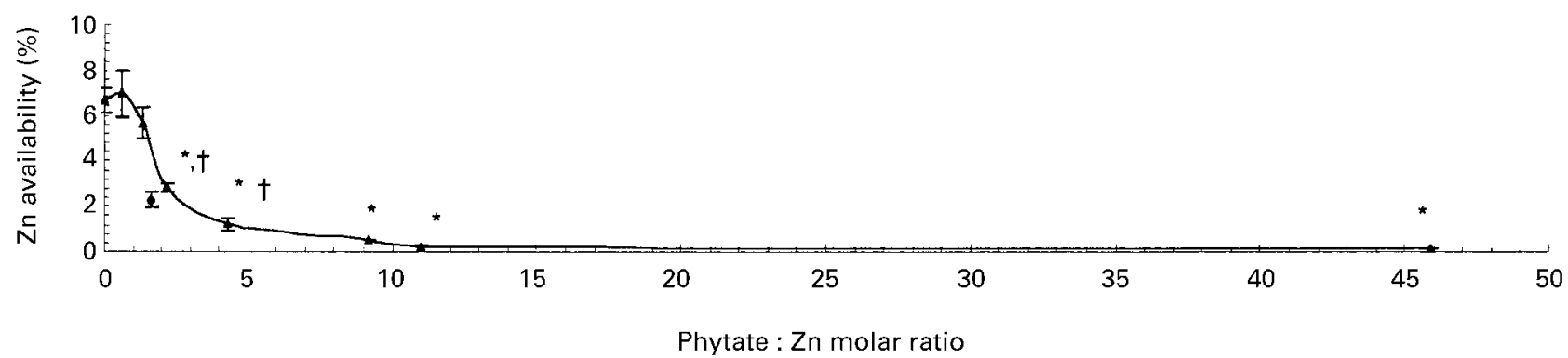

Fig. 1. Effect of phytate:zinc molar ratio on zinc availability from cows' milk-based $(\boldsymbol{\Lambda})$ and soyabean-based $(\bullet)$ infant formulas. Values are means for four determinations with standard deviations represented by vertical bars. For details of procedures, see p. 242. Mean values were significantly different from the non-supplemented cows' milk-based formula: ${ }^{*} P<0.05$. Mean values were not significantly different from the soyabean-based formula: $† P>0.05$.

\section{Assessment of the analytical performance of the in vitro procedure}

Recovery of Zn from sample 1 was 110 (SD 5) \% and from sample 2 was 107 (SD 5) \%. The repeatability of the method was $8.22 \%$ for the infant formula and $9.11 \%$ for the vegetable preparation $(N 4)$. Zn concentrations in the blank dialysates of method 1 were 0.038 (SD 0.005$) \mu \mathrm{g} / \mathrm{ml}$, and were subtracted from the infant formula dialysates. $\mathrm{Zn}$ concentrations in the blank dialysates in method 2 were $0.314(\mathrm{SD} 0.021) \mu \mathrm{g} / \mathrm{ml}$, and were subtracted from the green-bean dialysates.

\section{Zinc availability from the infant food samples}

$\mathrm{Zn}$ availability from infant formula with phytic acid decreased as the phytate:Zn molar ratio (and (phytate $\times \mathrm{Ca}): \mathrm{Zn}$ ratio) increased (Figs. 1 and 2). One-way ANOVA (with a Tukey post-hoc test for multiple comparisons) indicated a significantly lower in vitro $\mathrm{Zn}$ availability from infant formula when a phytate: $Z n$ molar ratio $2 \cdot 2(($ phytate $\times \mathrm{Ca}): \mathrm{Zn}$ ratio 256$)$ was obtained $(2 \cdot 84$ (SD $0.17) \%)$ as compared with the formula without phytate (6.65 (SD 0.55) \%) $(P<0.05)$. The test statistics also demonstrated significantly lower $\mathrm{Zn}$ availability from the soyabean-based formula (2.26 (SD 0.36$) \%)$ compared with the availability from the cows' milk-based formula (6.65 $(\mathrm{SD} 0.55) \%)(P<0.05)$. If the phytate: $\mathrm{Zn}$ molar ratio of the infant formula increased to $2 \cdot 2$ ((phytateXCa): Zn 256), Zn availability $(2 \cdot 84($ SD $0 \cdot 17) \%)$ was similar to the soyabeanbased formula (2.26 (SD 0.36) \%) $(P>0 \cdot 05)$.

The availability of $\mathrm{Zn}$ from an infant vegetable preparation decreased with increasing phytate:Zn molar ratio (and (phytate $\times \mathrm{Ca}$ ): $\mathrm{Zn}$ ratio) (Figs. 3 and 4). From the one-way ANOVA (Tukey post-hoc test) a significant decrease in $\mathrm{Zn}$ availability was found when the phytate: $\mathrm{Zn}$ molar ratio increased to the value of $7.9(($ phytate $\times \mathrm{Ca}): \mathrm{Zn}$ ratio 791$)(15.12$ (SD 1.63) \%), when compared with the vegetable preparation without added phytate (23.83 (SD $2 \cdot 17) \%)(P<0.05)$

\section{Discussion}

From this in vitro model $\mathrm{Zn}$ availability was $6 \cdot 65$ (SD 0.55) $\%$ from cows' milk-based formula, and 2.26 (SD 0.35) \% from soyabean-based infant formula. These results correspond well with data from in vivo studies. Ziegler et al. (1989) found net ${ }^{70} \mathrm{Zn}$ absorption by infants of $9 \cdot 1$ (SD 8.7) $\%$ from extrinsically labelled formulas. Lönnerdal (1994) and Hambidge et al. (1979) both showed significant lower plasma $\mathrm{Zn}$ levels in infants fed soyabean-based formula than infants fed cows' milk-based formula.

Using an in vitro method, we demonstrated that addition of phytate to cows' milk-formula (phytate:zinc 2.2; (phytate $\times \mathrm{Ca}$ ):Zn 256) at a level similar to that of soyabean-based formula (phytate:Zn molar ratio 1.6; (phytate $\times \mathrm{Ca}$ ): $\mathrm{Zn}$ ratio 208) caused a significant reduction in $\mathrm{Zn}$ availability so that it was similar to that from

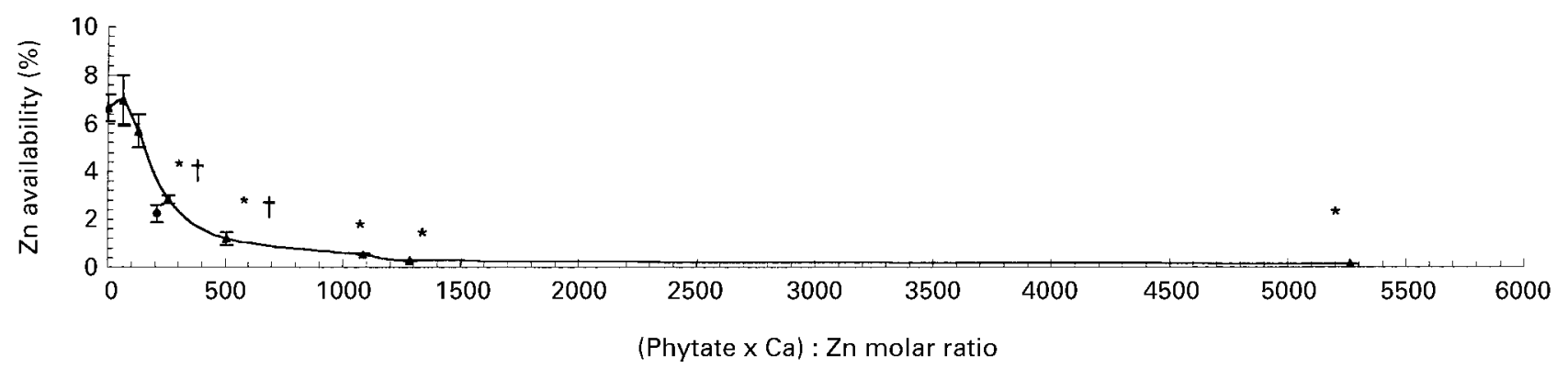

Fig. 2. Effect of (phytatexcalcium):zinc molar ratio on zinc availability from cows' milk-based ( $\mathbf{\Delta})$ and soyabean-based $(\bullet)$ infant formulas. Values are means for four determinations with standard deviations represented by vertical bars. For details of procedures, see $p$. 242 . Mean values were significantly different from the non-supplemented cows' milk based formula: ${ }^{*} P<0.05$. Mean values were not significantly different from the soyabean-based formula: $\dagger P>0.05$. 


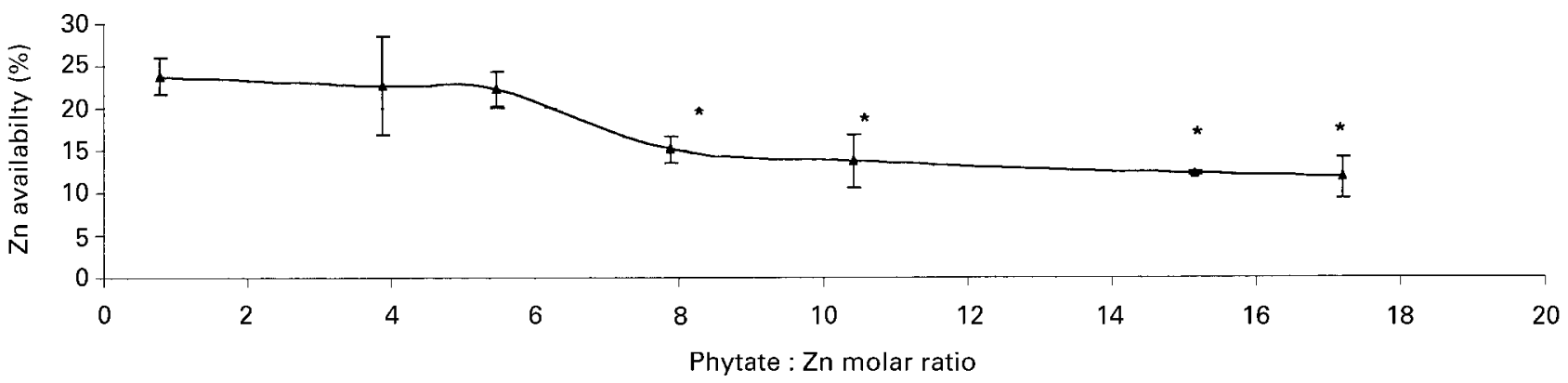

Fig. 3. Effect of phytate:zinc molar ratio on zinc availability from vegetables (green beans; Phaseolus vulgaris). Values are means for four determinations with standard deviations represented by vertical bars. For details of procedures, see p. 242 . Mean values were significantly different from the non-phytate-supplemented vegetables: * $P<0.05$.

soyabean-based formula (Figs. 1 and 2). These findings strongly suggest that the low availability of $\mathrm{Zn}$ from foods based on soyabean proteins may be attributed to their phytate content. These data are in agreement with studies performed by O'Dell \& Savage (1960) and Sandström et al. (1983a,b).

From this in vitro model it appeared that each step in increasing the phytate content of the infant food resulted in a stepwise decrease in $\mathrm{Zn}$ availability. These data are in agreement with studies performed by Lönnerdal et al. (1988), Rimbach et al. (1995) and Couzy et al. (1998), who have determined $\mathrm{Zn}$ absorption after intake of phytatecontaining foods. Our experiments on infant formula indicate that phytate: $\mathrm{Zn}$ molar ratios $>1 \cdot 5$, or (phytate $\times \mathrm{Ca}): \mathrm{Zn}$ molar ratios $>200$, can negatively affect $\mathrm{Zn}$ availability in vitro (Figs. 1 and 2). These results correspond well with the findings of Ellis et al. (1987), who indicated that human subjects who have a (phytate $\times \mathrm{Ca}): \mathrm{Zn}$ ratio $>200$ may have increased risk of impaired $\mathrm{Zn}$ bioavailability. From our in vitro results, $\mathrm{Zn}$ availability from the vegetable preparation markedly decreases if the phytate:Zn molar ratio increases to 7.9 , or when the ratio (phytate $\times \mathrm{Ca}$ ): $\mathrm{Zn}$ increases to 791 (Figs. 3 and 4). In the study of Bindra et al. (1986) serum Zn levels of Canadian omnivores were compared with those of Punjababi Sikhs having a diet that contained $90 \%$ more phytate, and $35 \%$ more $\mathrm{Ca}$, but $12 \%$ less Zn. Serum Zn levels of the Sikhs were much lower compared with the omnivores. The authors concluded that diets containing phytate: $\mathrm{Zn}$ ratios of $17 \cdot 7$, or (phytateX $\mathrm{Ca}): \mathrm{Zn}$ ratios $>500$, should be considered as problematic for man. Due to the different composition of both diets, it was argued that the Ca-potentiating effects, expressed as (phytate $\times \mathrm{Ca}$ ): $\mathrm{Zn}$, could have been responsible, but also the phytate content by itself.

In our present study, a whey protein-based infant formula was used as a vehicle for phytate because of its similar content compared with the soyabean protein-based infant formula, especially considering $\mathrm{Ca}$. In addition, the absence of phytate in this formula makes it possible to study the effect of phyate: $\mathrm{Zn}$ ratios $<1 \cdot 6$, without interference from inositol phosphate intermediaries.

Recently, the WHO included the phytate:Zn ratio of the food as criteria for categorising diets according to the potential availability of their $\mathrm{Zn}$ content (World Health Organization, 1996). Diets are characterised by low, moderate, or high bioavailablity according to their composition. Diets from which availability of $\mathrm{Zn}$ is low may contain high phytate, soyabean-protein products or have a phytate: $\mathrm{Zn}$ molar ratio $>15$. Moreover, high intakes of inorganic $\mathrm{Ca}$ salts, as is the case in soyabean-protein based infant formulas, are found to potentate the inhibitory effects of these low bioavailable diets (World Health Organization, 1996). Because of synergistic effects between phytate and high $\mathrm{Ca}$ on $\mathrm{Zn}$ absorption, the (phytate $\times \mathrm{Ca}$ ): $\mathrm{Zn}$ molar ratio of the diet is also frequently used to express $\mathrm{Zn}$ bioavailability (Oberleas \& Harland, 1981; Forbes et al. 1983).

It has been described that during industrial processing of soyabean proteins, phytates may be partly degraded into inositol phosphate intermediates (Liener, 1993), and that only inositol hexa- and pentaphosphates have a negative impact on Zn absorption (Lönnerdal et al. 1989; Sandström

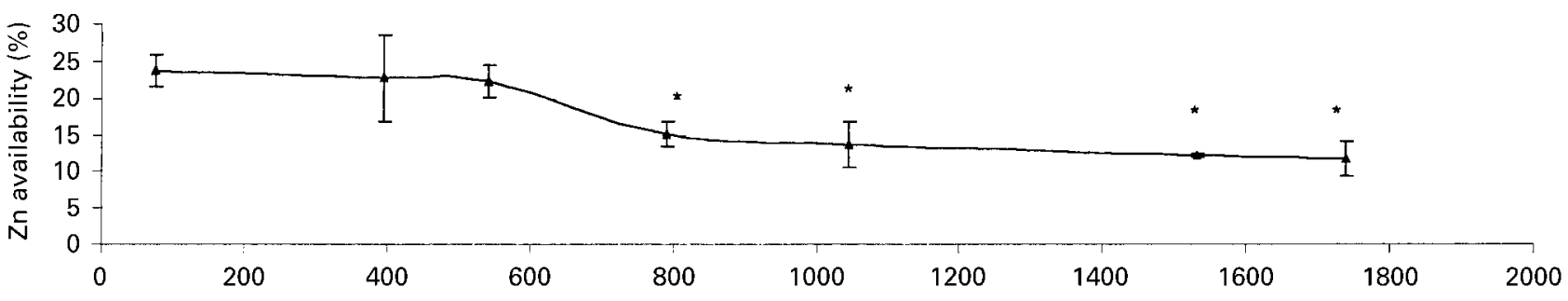

(Phytate $\times$ Ca) : Zn molar ratio

Fig. 4. Effect of (phytatexcalcium):zinc molar ratio on zinc availability from vegetables (green beans; Phaseolus vulgaris). Values are means for four determinations with standard deviations represented by vertical bars. For details of procedures, see $\mathrm{p}$. 242 . Mean values were significantly different from the non-phytate-supplemented vegetables: * $P<0.05$. 
\& Sandberg, 1992). Thus, knowledge about the levels of inositol hexa- and pentaphosphates may give some information about $\mathrm{Zn}$ availability. When considerable amounts of lower inositol phosphates (inositol tri- and tetraphosphates) are also present this seems to be an oversimplification. It appears that a mixture of inositol phosphates may have other effects than the pure fractions. Lower inositol phosphates (inositol tri- and tetraphosphates) may then also contribute to the inhibitory effect on $\mathrm{Zn}$ absorption (Sandström et al. 1987). According to Sandberg et al. (1993), Zn absorption may be correlated to the sum of inositol tri-phosphates to hexaphosphates in a number of composite meals. Because of the presence of appreciable amounts of lower inositol phosphate intermediaries in our soyabean protein-based formula, (phytate $\times \mathrm{Ca}$ ): $\mathrm{Zn}$ ratios were calculated from the sum of inositol triphosphates to hexaphosphates. However, since the addition of pure pentaor hexaphosphates has a major impact on $\mathrm{Zn}$ availability from phytate-enriched foods, (phytate $\times \mathrm{Ca}$ ): $\mathrm{Zn}$ ratios in whey-based formula and green beans were calculated using only both higher inositol phosphate intermediaries.

In general, it appears that phytate:Zn ratios $>1.5$ may inhibit $\mathrm{Zn}$ availability in small infants. After 6 months of life, this ratio increases to approximately 8 .

\section{Acknowledgements}

Dr Harry Robberecht thanks the University of Antwerp (UIA) for the use of research facilities on a freelance basis and the Plantijn Hogeschool (Antwerp) for accepting his additional scientific activity. The authors thank Dr Tess De Bruyne for critically reading the descriptions of the HPLC techniques. Dr Douwina Bosscher was supported by the Institute for the Promotion of Innovation by Science and Technology in Flanders.

\section{References}

Bender AE (1989) Nutritional significance of bioavailability. In Nutrient Bioavailability: Chemical and Biological aspects, pp. 3-9 [D Southgate, I Jackson and GR Fenwick, editors]. Dorset, UK: Dorset Press.

Bindra GS, Gibson RS \& Thompson LU (1986) (PhytateXcalcium)/zinc ratio in Asian immigrant lacto-ovo vegetarian diets and their relationship to zinc nutrient. Nutrition Research 6, 475-483.

Black MM (1998) Zinc deficiency and child development. American Journal of Clinical Nutrition 68, Suppl., 464S-469S.

Bosscher D, Van Caillie-Bertrand M \& Deelstra H (1998a) Beschikbaarheid van nutriënten: Optimalisatie van in vitro modellen voor kinderen jonger dan drie jaar (Availability of nutrients: optimalisation of in vitro models for children younger than three years old). Tijdschrift voor Gastro-Enterologie 36, $17-27$.

Bosscher D, Van Caillie-Bertrand M, Robberecht H, Van Dyck K, Van Cauwenbergh R \& Deelstra H (2001) In vitro availability of calcium, iron, and zinc from first age infant formula and human milk. Journal of Pediatric Gastroenterology and Nutrition 32, $54-58$.

Bosscher D, Van Dyck K, Robberecht H, Van Caillie-Bertrand M \& Deelstra H (1998b) Bioavailability of calcium and zinc from cow's milk-based versus soya-based infant food. International Journal of Food Sciences and Nutrition 49, 277-283.
Bougle D, Isfaoun A, Bureau F, Neuville D, Jauzac P \& Arhan P (1999) Long-term effects of iron:zinc interactions on growth in rats. Biological Trace Element Research 67, 37-48.

Champagne EL (1988) Effects of $\mathrm{pH}$ on mineral-phytate, protein-mineral-phytate and mineral-fiber interactions. Possible consequences of atropic disease on mineral bioavailability from high fiber foods. Journal of the American College of Nutrition 7, 499-508.

Cheryan M (1980) Phytic acid interactions in food systems. Critical Reviews in Food Science and Nutrition 13, 297-329.

Couzy F, Mansourian R, Labate A, Guinchard S, Montagne DH \& Dirren H (1998) Effect of dietary phytic acid on zinc absorption in the healthy elderly, as assessed by serum concentration curve tests. British Journal of Nutrition 80, 177-182.

De Vizia B \& Mansi A (1992) Calcium and phosphorus metabolism in full-term infants. Monatsschrift fur Kinderheilkunde 140, Suppl. 9, S8-S12.

Ellis R, Kelsay JL, Reynolds RD, Morris ER, Moser PB \& Frazier CW (1987) Phytate/zinc and phytateXcalcium/zinc millimolar ratio in self-selected diets of Americans, Asians Indians, and Nepalese. Journal of the American Dietetic Association 87, 1043-1047.

Forbes RM, Erdman JW, Parker HM, Kondo HM \& Ketelsen SM (1983) Bioavailability of zinc in coagulated soy protein (tofu) to rats and effects of dietary calcium at a constant phytate/zinc ratio. Journal of Nutrition 113, 205.

Frølich W (1990) Chelating properties of dietary fiber and phytate. The role for mineral availability. In New Developments in Dietary Fiber, pp. 83-93 [I Furda and CJ Brine, editors]. New York, NY: Plenum Press.

Hambidge K, Walravens P, Casey C, Brown RM \& Bendir C (1979) Plasma zinc concentrations of breast-fed infants. Journal of Pediatrics 9, 607-608.

Heaney RP, Weaver CM \& Fitzsimmons M (1991) Soybean phytate content: effect on calcium absorption. American Journal of Clinical Nutrition 53, 745-757.

Hendrix P, Van Cauwenbergh R, Robberecht H \& Deelstra H (1998) Daily dietary zinc intake in Belgium measured using duplicate portion sampling. Zeitschrift fur lebensmittel-untersuchung und-forschung A 206, 222-227.

Jackson MJ (1997) The assessment of bioavailability of micronutrients: introduction. European Journal of Clinical Nutrition 51, S1-S2.

Liener I (1993) Implications of antinutritional components in soybean foods. Critical Reviews in Food Science and Nutrition 34, $31-67$.

Lönnerdal B (1994) Nutritional aspects of soy formula. Acta Paediatrica 402, 105-108.

Lönnerdal B, Bell JG, Hendrickx AG, Bruns RA \& Keen CL (1988) Effect of phytate removal on zinc absorption from soyformula. American Journal of Clinical Nutrition $\mathbf{4 8}$, $1301-1306$.

Lönnerdal B, Sandberg AS, Sandström B \& Kunz C (1989) Inhibitory effects of phytic acid and other inositol phosphates on zinc and calcium absorption in suckling rats. Journal of Nutrition 119, 211-214.

Minihane AM, Fox TE \& Fairweather-Tait SJ (1993) A continuous flow in vitro method to predict bioavailability of Fe from foods. In Nutritional Chemical and Food Processing Implications of Nutrient Availability. Proceedings of Bioavailability'93, part 2, pp. 175-179 [U Schlemmer, editor]. Karlsruhe, Germany: Bundesforschungsanstalt für Ernärhung.

Morris E \& Ellis R (1980) Effect of dietary phytate/zinc molar ratio on growth and bone zinc response of rats fed semipurified diets. Journal of Nutrition 110, 1037-1045.

Nolan KB \& Duffin PA (1987) Effects of phytate on mineral bioavailability. In vitro studies on $\mathrm{Mg}, \mathrm{Ca}, \mathrm{Fe}, \mathrm{Cu}$ and $\mathrm{Zn}$ (also 
Cd). Solubilities in the presence of phytate. Journal of the Science of Food and Agriculture 40, 79-85.

Oberleas D \& Harland BF (1981) Phytate content of foods: effect on dietary zinc bioavailability. Journal of the American Dietetic Association 79, 433-436.

O'Dell BL \& Savage JE (1960) Effect of phytic acid on zinc availability. Proceedings of the Society for Experimental Biology and Medicine 103, 304-306.

Reddy NR, Sathe SK \& Salunkhe DK (1982) Phytates in legumes and cereals. Advances in Food Research 28, 1-92.

Rimbach G, Brandt K, Most E \& Pallauf J (1995) Supplemental phytic acid and microbial phytase change zinc bioavailability and cadmium accumulation in growing rats. Journal of Trace Elements in Medicine and Biology 9, 117-122.

Rimbach G, Walter A, Most E \& Pallauf J (1998) Effect of microbial phytase on zinc bioavailability and cadmium and lead accumulation in growing rats. Food and Chemical Toxicology 36, 7-12.

Sandberg AS \& Adherinne A (1986) HPLC method for determination of inositol tri-, tetra- penta-, and hexaphosphates in foods and intestinal contents. Journal of Food Science 51, $547-550$.

Sandberg AS, Brune M, Carlsson N, Hallberg L, RossanderHulthén L \& Sandström B (1993) The effect of various inositol phosphates on iron and zinc absorption in humans. In Nutritional Chemical and Food Processing Implications of Nutrient Availability. Proceedings of Bioavailability'93, part 2, pp. 53-57 [U Schlemmer, editor]. Karlsruhe, Germany: Bundesforschungsanstalt für Ernärhung.

Sandberg AS, Carlsson NG \& Svanberg U (1989) Effects of inositol tri-, tetra-, penta-, and hexaphosphates on in vitro estimation of iron availability. Journal of Food Science 54, 159-161.

Sandström B, Almgren A, Kivisto B \& Cederblad A (1987) Zinc absorption from meals based on rye, barley, oatmeal, triticale and whole-wheat. Journal of Nutrition 117, 1898-1902.

Sandström B, Cederblad A \& Lönnerdal B (1983a) Zinc absorption from human milk, cow's milk and infant formulas. American Journal of Diseases in Childhood 137, 726-729.

Sandström B, Keen CL \& Lönnerdal B (1983b) An experimental model for studies on zinc bioavailability from human milk and infant formulas using extrinsic labeling. American Journal of Clinical Nutrition 38, 420-428.

Sandström B \& Sandberg AS (1992) Inhibitory effects of isolated inositol phosphates on zinc absorption in humans. Journal of Trace Elements and Electrolytes in Health and Disease 6, 99-103.

Shankar AH \& Prasad AS (1998) Zinc and immune function: the biological basis of altered resistance to infection. American Journal of Clinical Nutrition 68, Suppl., 447S-463S.

Shen L, Luten J, Robberecht H, Bindels J \& Deelstra H (1994) Modification of an in vitro method for estimating the bioavailability of zinc and calcium from foods. Zeitschrift fur lebensmittel-untersuchung und-forschung A 199, 442-445.

Torre M \& Rodriguez AR (1991) Effects of dietary fiber and phytic acid on mineral availability. Critical Reviews in Food Science and Nutrition 1, 1-22.

Vandenplas Y (1992) Oesophageal pH monitoring: patient-related factors. In Oesophageal pH Monitoring for Gastro-esophageal Reflux in Infants and Children, pp. 253 [Y Vandenplas, editor]. London: John Wiley \& Sons Ltd..

Van Dyck K, Tas S, Robberecht H \& Deelstra H (1996) The influence of different food components on the in vitro availability of iron, zinc, and calcium from a composed meal International Journal of Food Science and Nutrition 47, 499-506.

Wise A (1995) Phytate and zinc bioavailability. International Journal of Food Science and Nutrition 46, 53-63.

World Health Organization (1996) Trace Elements in Human Nutrition and Health, Technical Report Series Geneva: WHO.

Ziegler EE, Serfass RE, Nelson SE, Figueroa-Colon R, Edwards BB, Houk RS \& Thompson JJ (1989) Effect of low zinc intake on absorption and excretion of zinc by infants studied with ${ }^{70} \mathrm{Zn}$ as extrinsic tag. Journal of Nutrition 119, 1647-1653. 